http://kitaibelia.unideb.hu/

ISSN 2064-4507 (Online) • ISSN 1219-9672 (Print)

(C) 2015, Department of Botany, University of Debrecen, Hungary

20 (1): 28-37.; 2015

DOI: $10.17542 /$ kit.20.28

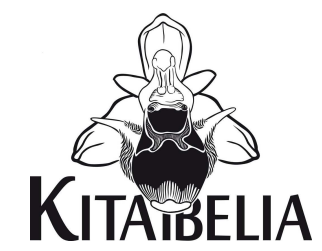

\title{
Campylopus flexuosus (Hedw.) Brid. a Nyugat-Mecsekben
}

\author{
CSIKY János $^{1 *}$, ERzBERgER, Peter ${ }^{2}$, KovÁcs Dániel ${ }^{1}$ \& DEME Judit ${ }^{1}$
}

(1) Pécsi Tudományegyetem TTK Biológiai Intézet, Ökológiai Tanszék, H-7624 Pécs, Ifjúság u. 6.; *moon@ttk.pte.hu (2) D-10823 Berlin, Belziger Str. 37., Germany

\section{Campylopus flexuosus (Hedw.) Brid. in the Western Mecsek Mts. (South Transdanubia, Hungary)}

\begin{abstract}
During a field survey in 2014, new localities of Campylopus flexuosus, were found in humid acidophilous oak and beech forests in the Western part of the Mecsek Mts. As a new element of the Hungarian bryoflora, C. flexuosus was discovered in 2013 in the Bakony Mts by Peter Erzberger and Csaba Németh. The localities of the sometimes extensive stands are enumerated, the size of the populations is estimated and the associated bryophyte and higher plant species are listed. Some morphological differences between $C$. flexuosus and the similar moss Dicranum flagellare are described and illustrated. Some interesting results of a revision of $D$. flagellare specimens in BP are compared with the actual distribution of $C$. flexuosus and lead to the conclusion that this species can be treated as a potentially expansive moss in humid acidophilous forests of the Mecsek Mts.
\end{abstract}

Keywords: acidophilous forest, Campylopus introflexus, Dicranum flagellare, invasive moss species

Összefoglalás - Egy mohaflorisztikai felmérés során, 2014-ben a Campylopus flexuosus új állományai kerültek elő a Nyugat-Mecsek humid, mészkerülő tölgyeseiben és bükköseiben. Az ország flórájára új fajt a Bakonyban elsőként Peter Erzberger és Németh Csaba mutatta ki 2013-ban. Az új, mecseki populációk feltárása során megbecsültük a $C$. flexuosus telepek kiterjedését, borítását, illetve listáztuk az állományokon belül előforduló moha és edényes növényfajokat. Munkánk során revideáltuk az MTM Növénytár (BP) Mohagyűjteményének D. flagellare anyagát. Ennek kapcsán bemutatjuk és ábrázoljuk a fajhoz makroszkopikusan igen hasonló Dicranum flagellare differenciális bélyegeit. Adataink alapján feltételezhető, hogy a $C$. flexuosus a mecseki humid, mészkerülő erdők egy új, terjedőben lévő mohafaja.

Kulcsszavak: Campylopus introflexus, Dicranum flagellare, inváziós moha mészkerülő erdők

\section{Bevezetés}

2014 szeptemberében, a juvenilis stádiumban lévő éger-völgyi Buxbaumia állományok egyedszámlálása során egy sötétzöld párnákban fejlődő, Leucobryum spp. szőnyegbe ágyazott Dicranaceae fajt találtunk. A mikroszkopikus bélyegek vizsgálata során megállapítottuk, hogy a talált növény azonosítható a Magyarországon elsőként a Bakonyban kimutatott Campylopus flexuosus-szal (ERZBERGER \& NÉMETH 2014). A felfedezést követően a hasonló élőhelyek szisztematikus bejárása során újabb populációkra bukkantunk. A potenciális lelőhelyeknek bizonyuló mészkerülő bükkösök és humid tölgyesek mohaflorisztikai szempontból a Mecsek legjobban kutatott területei közé tartoznak. Boros Ádám és Vajda László az 1960-as évekig többször is megfordultak a területen (vö. BoRos 1968, PAPP 2010, CSIKY et al. 2014, Fodor \& SzURDOKI 2014), de a C. flexuosus-t nem találták. 
PAPP (2010) 2007 augusztusában járt az Éger-völgyben és számos mohaflorisztikai ritkaságot mutatott ki a területről. A C. flexuosus-t ugyan megtalálta, viszont a hozzá igen hasonló, Magyarországon ritka Dicranum flagellare-ként azonosította, ugyanúgy, mint a második szerző, mikor 2014. október 7-én megfordult az Éger-völgyben. Ő is csak a később elvégzett mikroszkópos vizsgálat során bizonyosodott meg a moha valódi identitásáról. Ezek a tapasztalatok késztetettek minket arra, hogy revideáljuk az MTM Növénytár (BP) Mohagyüjteményében található $D$. flagellare példányokat, és hogy részletesen tanulmányozzuk a két faj között fennálló morfológiai különbségeket.

\section{Anyag és módszer}

A vizsgálati terület a Sopianicum flórajáráshoz tartozik (BoRHIDI 2003). A Jakabhegy déli oldalán, az Éger-völgyben, a Páprágy-völgyben és a Süle-völgyben az alsó-triász vörös homokkő (kisebb részt Kővágószőlősi Homokkő Formáció és nagyobb részt Jakabhegyi Homokkő Formáció), míg a Hideg-völgyben a triász-kori raeti homokkő (Karolinavölgyi Homokkő Formáció) jellemző (KonRÁD et al. 2010). A terület abiotikus adottságait CsiKY et al. (2014) korábbi cikkükben röviden jellemzik. A mohafajok határozását SMITH (2004), ORBÁN \& VAJDA (1983) és FRAHM \& FREY (1992) kulcsai, az edényes növények azonosítását KIRÁLY (2009) könyve alapján végeztük. Nomenklatúrai tekintetben a moháknál PAPP et al. (2010) dolgozatához (kivéve a Cynodontium polycarpon-t, ahol HILL et al. (2006) monográfiáját követjük), az edényes növények esetében KIRÁLY (2009) munkájához igazodtunk. A növényzeti típusok felismeréséhez KEVEY \& BORHIDI (2005) leírásait használtuk. A mohák veszélyeztetettségi kategóriáit PAPP et al. (2010) alapján adtuk meg. A begyűjtött példányokat a Pécsi Tudományegyetem (JPU) és részben a Botanischer Garten und Botanisches Museum Berlin-Dahlem (B) moha kollekciójában helyeztük el. A lelőhelyek koordinátáit GPS készülékkel rögzítettük. A mohák által elfoglalt terület nagyságának meghatározását terepi méréssel, egyes esetekben GPS koordináták alapján, a borításukat \%os becsléssel végeztük. A herbáriumi példányok begyűjtését, határozását és a lelőhelyek felvételezését az adott állományon belül ugyanazon személyek végezték. A listákban az aláhúzott nevek a domináns fajokat jelzik. Az MTM Növénytár (BP) Dicranum flagellare anyagának revízióját a második szerző végezte. Az 1. táblázat adatai a következő példányok vizsgálatán alapulnak: Dicranum flagellare: B-Erzberger 6688: Budapest, Nagy- Hárs-hegy 07.02.2001 leg. Erzberger; Campylopus flexuosus: B-Erzberger 19163: Pécs, Hideg-völgy 09.10.2014 leg. Csiky \& Erzberger. Ehhez hitelesített okulárskálával ellátott Wild M3Z sztereomikroszkópot és Leitz Biomed fénymikroszkópot, az ugyanezen példányok alapján készült rajzokhoz (1. ábra) Leitz rajztubust használtunk. A levélkeresztmetszetek borotvapengével készültek.

\section{Eredmények}

Állományok felsorolása

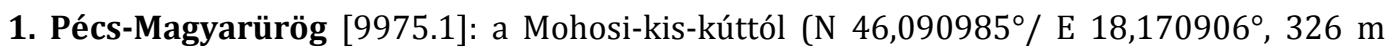
tszf.) az Éger-völgyig (N 46,092413\% / E 18,174955', 286 m tszf.) tartó mecseki mészkerülő bükkösben a Mecsekre új C. flexuosus (2014.09.12., leg./det.: Csiky J.) szinte mindenütt megtalálható, általában a pár $\mathrm{cm}^{2}$-estől a néhány $\mathrm{dm}^{2}$-es foltokig, mindig Leucobryum spp. párnákba ágyazottan. Megfigyeléseink szerint ahol a Leucobryum spp. nagyobb párnái eltűnnek a mohaszintből, ott a C. flexuosus sem található meg. Az állomány összborítás becslése a kis, elszórt párnák miatt igen nehéz, de egy $500 \mathrm{~m}^{2}$-es próba területen $5 \mathrm{~m}^{2}$, azaz 1\%-os volt. Kísérő mohafajok: Bazzania trilobata, Buxbaumia aphylla, Cephalozia bicuspidata, Dicranella heteromalla, Dicranum scoparium, D. tauricum, Diphyscium foliosum, Ditrichum 
heteromallum, Hypnum cupressiforme, Jamesoniella autumnalis, Lepidozia reptans, Leucobryum spp., Lophocolea heterophylla, Lophozia bicrenata, Plagiochila porelloides, Pohlia nutans, Polytrichum formosum, P. piliferum, Pseudotaxiphyllum elegans, Scapania nemorea. Kísérő edényes növények: Fagus sylvatica, Festuca drymeia, Genista pilosa, Hieracium spp., Loranthus europaeus, Luzula luzuloides, Melampyrum pratense, Monotropa hypopitys, Platanthera bifolia, Polypodium vulgare, Quercus petraea.

2. Pécs-Lámpásvölgy [9875.3]: a Hideg-völgyben a Hideg-kúttól keletre eső mecseki mészkerülő bükkös és humid mészkerülő tölgyes átmenetében ( $\mathrm{N} 46,105341^{\circ}$ / E

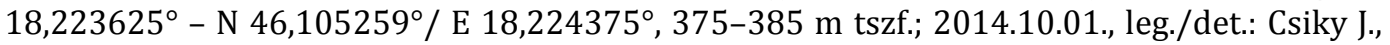
Deme J., Kovács D.); mintegy $500 \mathrm{~m}^{2}$-en a pár $\mathrm{cm}^{2}$-estől a néhány $\mathrm{dm}^{2}$-es foltokig, 1-2\%-os összborítással. A Fagus sylvatica és Quercus petraea átmeneti zónájában, a Dicranum scoparium és a Leucobryum spp. küzdelmi sávjában mindkét faj mohapárnájába ágyazottan jellemző, de előfordul csupasz talajon is. Kísérő mohafajok: Cephalozia bicuspidata, Dicranella heteromalla, Dicranum scoparium, Hypnum cupressiforme, Leucobryum spp., Lophocolea heterophylla, Lophozia bicrenata, Pohlia nutans, Polytrichum formosum, P. piliferum, Pseudotaxiphyllum elegans, Scapania nemorea. E folt közelében, a mészkerülő bükkösben itt is megtalálható a Diphyscium foliosum, illetve a Buxbaumia aphylla. Kísérő edényes növények: Castanea sativa, Campanula persicifolia, Carex digitata, Fagus sylvatica, Festuca heterophylla, Fraxinus ornus, Genista pilosa, Hieracium spp., Hypericum perforatum, Loranthus europaeus, Luzula luzuloides, Melampyrum pratense, Molinia arundinacea, Pinus nigra, Poa nemoralis, Quercus petraea, Q. rubra, Veronica officinalis.

3. Pécs-Patacs [9974.2]: Páprágy-völgyben az északi oldal felső felének mecseki mészkerülő bükkösében és telepített fekete fenyvesekben (N 46,088754\% $/$ E $18.160509^{\circ}-\mathrm{N}$ $46.089160^{\circ}$ / E 18,158136², 425-455 m tszf.; 2014.10.02., leg./det.: Csiky J.); mintegy 1500 $\mathrm{m}^{2}$-en a pár $\mathrm{cm}^{2}$-estől a néhány $\mathrm{dm}^{2}$-es foltokig, 1\%-os összborítással. Általában Leucobryum spp., Dicranum scoparium és Dicranella heteromalla párnákban, de csupasz talajon és korhadó fekete fenyő tönkön is. Kísérő mohafajok: Buxbaumia aphylla, Cephalozia bicuspidata, Dicranella heteromalla, Dicranum scoparium, Hypnum cupressiforme, Lepidozia reptans, Leucobryum spp., Lophocolea heterophylla, Pohlia nutans, Polytrichum formosum, P. piliferum, Pseudotaxiphyllum elegans. Kísérő edényes növények: Fagus sylvatica, Hieracium spp., Loranthus europaeus, Luzula luzuloides, Monotropa hypopitys, Pinus nigra, Polypodium vulgare, Quercus cerris, Q. petraea, Sorbus torminalis, Vaccinium vitis-idaea.

4. Pécs-Patacs [9974.2]: Süle-völgyben a völgy nyugati oldalában (N 46,08100\% $\mathrm{E}$ 18,16353, 317 m tszf.; 2014.12.02., leg./det.: Csiky J.); $1 \mathrm{~m}^{2}$-en legfeljebb $1 \mathrm{dm}^{2}$-es foltok, 2\%-os összborítással. Kísérő mohafajok: Cephaloziella sp., Dicranum scoparium, Hypnum cupressiforme, Pohlia nutans. Kísérő edényes növények: Loranthus europaeus, Pinus nigra, Quercus cerris, Q. petraea, Rumex acetosella.

5. Cserkút: Fonyó-hát [9974.2], telepített fenyvesben illetve a zöld turistaút menti mészkerülő tölgyesekben több helyen.

5/a N 46,084288 \% E 18,150489 , 486 m tszf.; 2014.12.02., leg./det.: Deme J., Kovács D.; $30 \times 20$ m-es állomány legfeljebb $1 \mathrm{~m}^{2}$-es foltok, 0,1\%-os összborítással. Kísérő mohafajok: Campylopus introflexus, Cephalozia bicuspidata, Dicranella heteromalla, Dicranum scoparium, Hypnum cupressiforme, Leucobryum spp., Pohlia nutans, Polytrichum formosum, P. piliferum. Kísérő edényes növények: Loranthus europaeus, Luzula luzuloides, Pinus nigra, Quercus petraea, Rumex acetosella.

5/b N 46,083046 \% E 18,151462 ㅇ, 455 m tszf.; 2014.12.02., leg./det.: Deme J., Kovács D.; $10 \times 10$ m-es állomány legfeljebb $4 \mathrm{~m}^{2}$-es foltok, $15 \%$-os összborítással. Kísérő mohafajok: Dicranum scoparium Hypnum cupressiforme, Leucobryum spp., Pohlia nutans, Polytrichum 
formosum, P. piliferum. Kísérő edényes növények: Hieracium sabaudum, Loranthus europaeus, Luzula luzuloides, Pinus nigra, Quercus petraea, Rumex acetosella.

5/c N 46,083330 E 18,151842² 457 m tszf.; 2014.12.02., leg./det.: Deme J., Kovács D.; 2 × 6 m-es állomány legfeljebb $2 \mathrm{dm}^{2}$-es foltok, 4\%-os összborítással. Kísérő mohafajok: Dicranum scoparium, Hypnum cupressiforme, Pohlia nutans, Polytrichum formosum. Kísérő edényes növények: Luzula luzuloides, Pinus nigra, Quercus petraea.

5/d N 46,08367º E 18,15368 428 m tszf.; 2014.12.02., leg./det.: Deme J., Kovács D.; 50 × 30 m-es állomány legfeljebb $2 \mathrm{dm}^{2}$-es foltok, 0,03\%-os összborítással. Kísérő mohafajok: Cephaloziella sp., Dicranum scoparium, Hypnum cupressiforme, Pohlia nutans. Kísérő edényes fajok: Luzula luzuloides, Pinus nigra, Quercus petraea.

5/e N 46,083270 E 18,154090 423 m tszf.; 2014.12.02., leg./det.: Deme J., Kovács D.; $40 \times 20 \mathrm{~m}$-es állomány legfeljebb $3 \mathrm{dm}^{2}$-es foltok, 0,01\%-os összborítással. Kísérő mohafajok: Cephaloziella sp., Dicranum scoparium Hypnum cupressiforme. Kísérő edényes fajok: Luzula luzuloides, Pinus nigra, Quercus petraea.

5/f N 46,083097\% E 18,154611 413 m tszf.; 2014.12.02., leg./det.: Deme J., Kovács D.; $15 \times 10$ m-es állomány legfeljebb $1 \mathrm{~m}^{2}$-es foltok, 3\%-os összborítással. Kísérő mohafajok: Cynodontium polycarpon, Dicranum scoparium, Hypnum cupressiforme, Pohlia nutans, Polytrichum formosum, P. piliferum. Kísérő edényes növények: Loranthus europaeus, Luzula luzuloides, Pinus nigra, Quercus petraea.

6. Kővágószőlős: a Jakabhegy déli oldalán [9974.2] a platóperemtől a kertekkel határos erdőszélig több helyen.

6/a N 46,092853/ E 18,128862², 418 m tszf.; 2014.11.07., leg./det.: Csiky J., Deme J., Kovács D.; $10 \times 50$ m-es állomány legfeljebb $2 \mathrm{~m}^{2}$-es foltok, 1\%-os összborítással. Kísérő mohafajok: Dicranella heteromalla, Dicranum scoparium, Hypnum cupressiforme, Leucobryum spp., Lophocolea heterophylla, Pohlia nutans, Polytrichum formosum. Kísérô edényes növények: Fagus sylvatica, Fraxinus ornus, Genista pilosa, Hieracium sp., Loranthus europaeus, Luzula luzuloides, Melampyrum pratense, Quercus petraea, Rumex acetosella.

6/b N 46,091362 / E 18,134407 444 m tszf.; 2014.11.07., leg./det.: Csiky J., Deme J., Kovács D.; $20 \times 20$ m-es állomány legfeljebb $3 \mathrm{dm}^{2}$-es foltok, 0,5\%-os összborítással. Kísérő mohafajok: Campylopus introflexus, Cephaloziella sp., Ceratodon purpureus, Dicranella heteromalla, Dicranum scoparium, Hypnum cupressiforme, Leucobryum spp., Pohlia nutans, Polytrichum formosum, P. piliferum. Kísérő edényes növények: Fraxinus ornus, Genista pilosa, Hieracium sp., Loranthus europaeus, Luzula luzuloides, Quercus petraea, Rumex acetosella.

6/c N 46,093156\% E 18,136712º, 527 m tszf.; 2014.11.07., leg./det.: Csiky J., Deme J., Kovács D.; $50 \times 70 \mathrm{~m}$-es állomány legfeljebb $3 \mathrm{dm}^{2}$-es foltok, 0,5\%-os összborítással. Kísérő mohafajok: Bryum argenteum, Ceratodon purpureus, Cynodontium polycarpon Dicranella heteromalla, Dicranum scoparium, Hypnum cupressiforme, Pohlia nutans, P. schimperi, Polytrichum piliferum. Kísérő edényes növények: Fagus sylvatica, Genista pilosa, Luzula forsteri, L. luzuloides, Quercus petraea, Rumex acetosella.

6/d N 46,09607\% / E 18,12985, 527 m tszf.; 2014.11.07., leg./det.: Csiky J., Deme J., Kovács D.; $20 \times 30$ m-es állomány legfeljebb $3 \mathrm{dm}^{2}$-es foltok, 0,1\%-os összborítással. Kísérő mohafajok: Campylopus introflexus, Ceratodon purpureus, Dicranella heteromalla, Dicranum scoparium, Hypnum cupressiforme, Pohlia nutans, Polytrichum piliferum. Kísérő edényes növények: Fagus sylvatica, Loranthus europaeus, Luzula luzuloides, Quercus petraea, Rumex acetosella. 
6/e N 46,09184 / E 18,139002 485 m tszf.; 2014.11.25., leg./det.: Deme J., Kovács D.; 80 × 20 m-es állomány legfeljebb $1 \mathrm{dm}^{2}$-es foltok, 0,1\%-os összborítással. Kísérő mohafajok: Campylopus fragilis, Cephaloziella sp., Dicranella heteromalla, Hypnum cupressiforme, Pohlia nutans. Kísérő edényes növények: Fraxinus ornus, Hieracium sp., Loranthus europaeus, Luzula luzuloides, Quercus petraea, Rubus fruticosus, Rumex acetosella.

6/f N 46,091795 E 18,139671 490 m tszf.; 2014.11.25., leg./det.: Deme J., Kovács D.; $100 \times 100$ m-es állomány legfeljebb $2 \mathrm{~m}^{2}$-es foltok, 0,5\%-os összborítással. Kísérő mohafajok: Cynodontium polycarpon, Dicranella heteromalla, Hypnum cupressiforme, Pohlia nutans, P. schimperi, Polytrichum piliferum. Kísérő edényes növények: Fagus sylvatica, Fraxinus ornus, Loranthus europaeus, Luzula luzuloides, Quercus petraea, Rumex acetosella.

6/g N 46,090763 / E 18,142102 504 m tszf.; 2014.11.25., leg./det.: Deme J., Kovács D.; $30 \times 80$ m-es állomány legfeljebb $1 \mathrm{~m}^{2}$-es foltok, 0,1\%-os összborítással. Kísérő mohafajok: Dicranella heteromalla, Dicranum scoparium, Hypnum cupressiforme $\underline{\text { Pohlia }}$ nutans, Polytrichum formosum. Kísérő edényes növények: Fraxinus ornus, Hieracium sp., Loranthus europaeus, Luzula luzuloides, Quercus petraea, Rumex acetosella.

6/h N 46,090454 / E 18,143038, 512 m tszf.; 2014.11.25., leg./det.: Deme J., Kovács D.; $20 \times 20$ m-es állomány legfeljebb $2 \mathrm{~m}^{2}$-es foltok, 0,1\%-os összborítással. Kísérő mohafajok: Campylopus introflexus, Cynodontium polycarpon, Hypnum cupressiforme, Pohlia nutans, Polytrichum piliferum. Kísérő edényes növények: Fagus sylvatica, Loranthus europaeus, Luzula luzuloides, Quercus petraea, Rumex acetosella.

6/i N 46,087794 / E 18,146463ํ 550 m tszf.; 2014.11.25., leg./det.: Deme J., Kovács D.; $90 \times 100$ m-es állomány legfeljebb $5 \mathrm{~m}^{2}$-es foltok, 1\%-os összborítással. Kísérő mohafajok: Cephaloziella sp., Ceratodon purpureus, Cynodontium polycarpon, Dicranella heteromalla, Dicranum scoparium, Hypnum cupressiforme, Leucobryum spp., Pohlia nutans, Polytrichum formosum, P. piliferum. Kísérő edényes növények: Fagus sylvatica, Loranthus europaeus, Luzula luzuloides, Quercus petraea, Rumex acetosella.

6/j N 46,094456\% / E 18,12682 416 m tszf.; 2014.11.25., leg./det.: Csiky J.; 50 × 30 m-es állomány legfeljebb 0,5m²-es foltok, 1\%-os összborítással. Kísérő mohafajok: Campylopus introflexus, Cephaloziella sp., Cynodontium polycarpon, Dicranella heteromalla, Dicranum scoparium, Dicranum tauricum, Hypnum cupressiforme, Pohlia nutans, Polytrichum formosum, P. piliferum. Kísérő edényes növények: Fagus sylvatica, Genista pilosa, Hieracium bauhinii, Loranthus europaeus, Luzula luzuloides, Quercus petraea, Rumex acetosella.

6/k N 46,096342 / E 18,127941ํ, 540 m tszf.; 2014.11.25., leg./det.: Csiky J.; 8 × 5 m-es állomány legfeljebb $1 \mathrm{dm}^{2}$-es foltok, 0,1\%-os összborítással. Kísérő mohafajok: Bryum argenteum, Campylopus fragilis, Campylopus introflexus, Cephaloziella sp. Cynodontium polycarpon, Dicranum scoparium, Pohlia nutans, Polytrichum piliferum. Kísérő edényes növények: Loranthus europaeus, Luzula luzuloides, Quercus petraea Rumex acetosella.

6/1 N 46,09761\% / E 18,124942 532 m tszf.; 2014.11.25., leg./det.: Csiky J.; 5 × 30 m-es állomány legfeljebb $0,5 \mathrm{~m}^{2}$-es foltok, 4\%-os összborítással. Kísérő mohafajok: Cynodontium polycarpon, Dicranella heteromalla, Dicranum scoparium, Hypnum cupressiforme, Pohlia nutans, Polytrichum formosum, P. piliferum. Kísérő edényes növények: Fagus sylvatica Loranthus europaeus, Luzula luzuloides, Quercus petraea Rumex acetosella.

6/m N 46,09632 ${ }^{\circ}$ E 18,128103ㅜ, 543 m tszf.; 2014.11.25., leg./det.: Csiky J.; $100 \times 40$ mes állomány legfeljebb 0,5 $\mathrm{dm}^{2}$-es foltok, 1\%-os összborítással. Kísérő mohafajok: 
Campylopus introflexus, Cephaloziella sp., Cynodontium polycarpon, Dicranella heteromalla, Dicranum scoparium, Hypnum cupressiforme, Leucobryum spp., Pohlia nutans, Polytrichum piliferum. Kísérő edényes növények: Fagus sylvatica, Loranthus europaeus, Luzula luzuloides, Quercus petraea, Rumex acetosella.

\section{A Dicranum flagellare revízió eredményei}

A megvizsgált 25 D. flagellare példány közül kettőben sikerült Campylopus flexuosus-t találni, az összes többi (1 kivétellel: BP 100293 BoRos Ádám: Comit. Gömör. Ad truncos putresc. silvat. Haragistya inter Szilice et Aggtelek, 500 m a.s.l. 15.06.1953, amely valójában Dicranum montanum) helyesen volt határozva. Az említett két példány a következő:

1. BP 100294, Comit. Zala. In rupibus arenaceis Betuletorum supra vallem Lesence prope Uzsa, $200 \mathrm{~m}$ a.s.l., leg./det.: Boros Ádám: 22.09.1953.

BoROS meghatározását megerősítettük, de a mintában a revideálás során néhány szál Campylopus flexuosus is előkerült. Revid.: Peter ERZBERgER, 20.10.2014.

2. BP 174340, Baranya County, Mecsek Mts, Éger valley at Pécs, acidic soil in Fagetum

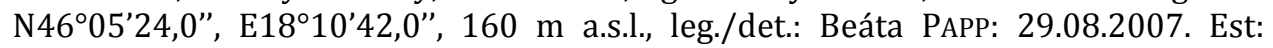
Campylopus flexuosus. Revid.: Peter ERZBERGER, 20.10.2014.

(Megjegyzésre érdemes, hogy a koordináták alapján a helyes tszf. magasság $260 \mathrm{~m}$. A megadott 160 m tszf-i magasságban a Mecsek D-i felében bükkösök nem találhatók.)

A fentiek tükrében érdemes a két faj alaposabb összehasonlítását elvégezni (1. táblázat), ugyanis megjelenésük vegetatív állapotban egymáshoz megtévesztően hasonló lehet (azonos méret, az elágazó száracska csúcsán flagellumok, enyhén hajlott levélkék, rhizoidok megléte, saroksejtek nagyok, négyszögletesek), színükben, a flagellum felépítésében és a levélke keresztmetszeti képében azonban egyértelműen eltérnek (1. ábra).

1. táblázat. A Campylopus flexuosus és a Dicranum flagellare elkülönítését segítő legfontosabb bélyegek Table 1. Important differential characteristics of Campylopus flexuosus and Dicranum flagellare.

\begin{tabular}{|c|c|c|}
\hline & Campylopus flexuosus & Dicranum flagellare \\
\hline $\begin{array}{l}\text { flagellum szélessége/ } \\
\text { width of flagellum }\end{array}$ & $240-420 \mu \mathrm{m}$ & $150-200 \mu \mathrm{m}$ \\
\hline $\begin{array}{l}\text { flagellum hossza/ } \\
\text { length of flagellum }\end{array}$ & $2,4-3,5 \mathrm{~mm}$ & $1,5-2,5 \mathrm{~mm}$ \\
\hline $\begin{array}{l}\text { flagellum csúcsi } \\
\text { levélkéjének alakja/ } \\
\text { shape of uppermost } \\
\text { (distal) leaflet of } \\
\text { flagellum }\end{array}$ & $\begin{array}{l}\text { keskeny lándzsás, csúcsa kihegyesedő, } \\
\text { a végén gyengén fogas / } \\
\text { narrowly lanceolate, apex acuminate, a } \\
\text { few denticulations near extreme apex }\end{array}$ & $\begin{array}{l}\text { tojásdad, homorú, tompa, } \\
\text { fogatlan csúcsú / } \\
\text { ovate, concave, apex obtuse, } \\
\text { without denticulations }\end{array}$ \\
\hline $\begin{array}{l}\text { telep színe/ } \\
\text { colour of the stand }\end{array}$ & sötétzöld / dark green & $\begin{array}{l}\text { élénkzöld, sárgászöld / mid- } \\
\text { to yellow-green }\end{array}$ \\
\hline $\begin{array}{l}\text { levélér keresztmetszet/ } \\
\text { cross section of costa }\end{array}$ & $\begin{array}{l}\text { legfelső, adaxiális sejtsora tág lumenü, } \\
\text { rendezett / } \\
\text { the uppermost, adaxial cells with wide } \\
\text { lumina, ordered in one row }\end{array}$ & $\begin{array}{c}\text { legfelső, adaxiális sejtsora } \\
\text { szúk lumenü, rendezetlen / } \\
\text { the uppermost, adaxial cells } \\
\text { with narrow lumina, } \\
\text { arranged in irregular row }\end{array}$ \\
\hline $\begin{array}{l}\text { levélér vastagsága/ } \\
\text { width of costa }\end{array}$ & $\begin{array}{l}\text { a levél alapjának min. } 1 / 3-a / \\
\text { wider than the } 1 / 3 \text { of the leaf base }\end{array}$ & $\begin{array}{l}\text { a levél alapjának max. } 1 / 3-a / \\
\text { not wider than the } 1 / 3 \text { of the } \\
\text { leaf base }\end{array}$ \\
\hline
\end{tabular}




\section{Megvitatás}

A 317-550 méter tengerszint feletti magasság között fejlődő állományok döntő többsége Quercus petraea s.l., kisebb része Fagus sylvatica uralta üde, mészkerülő erdőben található. A sekély, tápanyagban szegény talaj következtében felnyíló lombkoronára utal a Loranthus europaeus relatív gyakorisága (83\%). Az ilyen erdők többségében a cserjeszint hiányzik, a gyepszint gyér, a mohaszint viszont igen fejlett. Az érintett állományokban a gyepszint fajai közül leggyakrabban a Luzula luzuloides-szel (96\%) és a Rumex acetosella s.l.-val (70\%) találkozhatunk. A mohaszint leggyakoribb uralkodó faja a Dicranum scoparium (87\%), de a bükkösökben a Leucobryum spp. jellemzőbb. Gyakori kísérő még a Hypnum cupressiforme (96\%), Pohlia nutans (96\%), Polytrichum piliferum (70\%), Dicranella heteromalla (65\%), a Polytrichum formosum (57\%) és a Cephaloziella sp. (43\%). A mészkerülő erdőkön belül, a termőhelyek üdeségét jelző gyakoribb fajok a Fagus sylvatica (52\%), a Luzula luzuloides, a Dicranum scoparium és a Polytrichum formosum.

A Mecsekben a C. flexuosus összesítve 6 ha-nyi erdőállományban elszórtan, a néhány $\mathrm{cm}^{2}$ es párnácskáktól az $5 \mathrm{~m}^{2}$-es szőnyegszerű foltokig, általában a domináns moha párnái közé ékelődve található, annak rovására terjeszkedik. Kisebb telepei a csupasz felszínen sőt, korhadó tuskókon, fák tövénél is megtalálhatók. A faj becsült összborítása a felmért területen mintegy $450 \mathrm{~m}^{2}$.

A C. flexuosus-nak csak vegetatív szaporodását figyeltük meg a Mecsekben. A propagulumok, fiatal egyedek, teleptöredékek igen könnyen beékelődhetnek a kisebbnagyobb szőnyegekbe, párnákba, ahol növekedésnek indulva kiszorítják az uralkodó mohát. A C. flexuosus igen sűrű gyepje alatt a nagyobb termetű, konkurens mohák (pl. Dicranum scoparium, Leucobryum spp.) egyedei ugyanis fény hiányában elhalnak. A Campylopus telep növekedésével a kialakuló szőnyeg feltöredezik, száraz időben szétesik, vagy nagyobb darabokban kifordulva (például taposás hatására) lejtésirányban tovább terjed. A vegetatív szaporodás egy másik igen hatékony módja a száracska csúcsrügyecskéinek, illetve flagellumainak letöredezése. A leválás után a kalászka-szerú rügyecskék az alapjuknál sugarasan rendeződő rhizoidokat fejlesztenek. Ennek köszönhetően a C. flexuosus a teljesen csupasz erdei talaj humuszban gazdag felszínén is hatékonyan képes megtapadni. A faj megtelepedéséhez tehát nincs szükség befogadó mohapárna jelenlétére. Mégis, legtöbbször olyan állományokkal találkozunk, ahol a domináns mohákba ágyazottan fejlődik a telepek nagy része. A mészkerülő erdők sajátságait (például fejlett mohaszint) ismerve azonban ez egyáltalán nem meglepő (vö. KEVEY \& BORHIDI 2005). A leggyakoribb és tömegesebb kísérő fajainak fennmaradására a C. flexuosus expanziója rövidtávon nincs hatással. A helyileg ritkább, fóként Leucobryum-ok párnáiban élő májmohák (például Bazzania trilobata - NT, Jamesoniella autumnalis - NT) és az itt jellemző, friss talajfelszíneken kolonizáló, országosan is ritkább fajok veszélyeztetettsége (például Buxbaumia aphylla - VU, Scapania nemorea VU) már komolyabb kérdéseket vet fel. Mindkét probléma monitoring vizsgálatokkal tisztázható lenne.

A C. flexuosus nagy, mecseki állományai kapcsán felmerül a kérdés, hogy korábban miért nem találták meg e fajt, illetve e moha mióta élhet itt. A Mecsekben e mohát elsőként PAPP (2010) az Éger-völgyben gyüjtötte (BP 174340), ám tévesen Dicranum flagellare-ként azonosította. Ez utóbbi, igen hasonló megjelenésű faj a célzott keresés ellenére, a területről azóta sem került elő. Az MTM Növénytárának Mohagyűjteményében (BP) található $D$. flagellare anyagok áttekintésekor az is kiderült, hogy a C. flexuosus első magyarországi példánya BoRos Ádám gyújtése alapján Uzsáról származik. BoRos D. flagellare anyagában (BP 100294) ugyanis a revideálás során néhány szál $C$. flexuosus is előkerült. Mindezek alapján a C. flexuosus már legalább 60 éve tagja a magyar mohaflórának. Boros és Vajda aktív és átfogó kutatásának fényében arra is következtethetünk, hogy abban az időben a faj valószínűleg 
csak igen kis mennyiségben volt jelen a területen. Úgy tűnik tehát, hogy populációinak egyedszáma az elmúlt évtizedek alatt megnövekedett (vö. ERZBERGER \& NÉMETH 2014).

\section{Campylopus flexuosus}

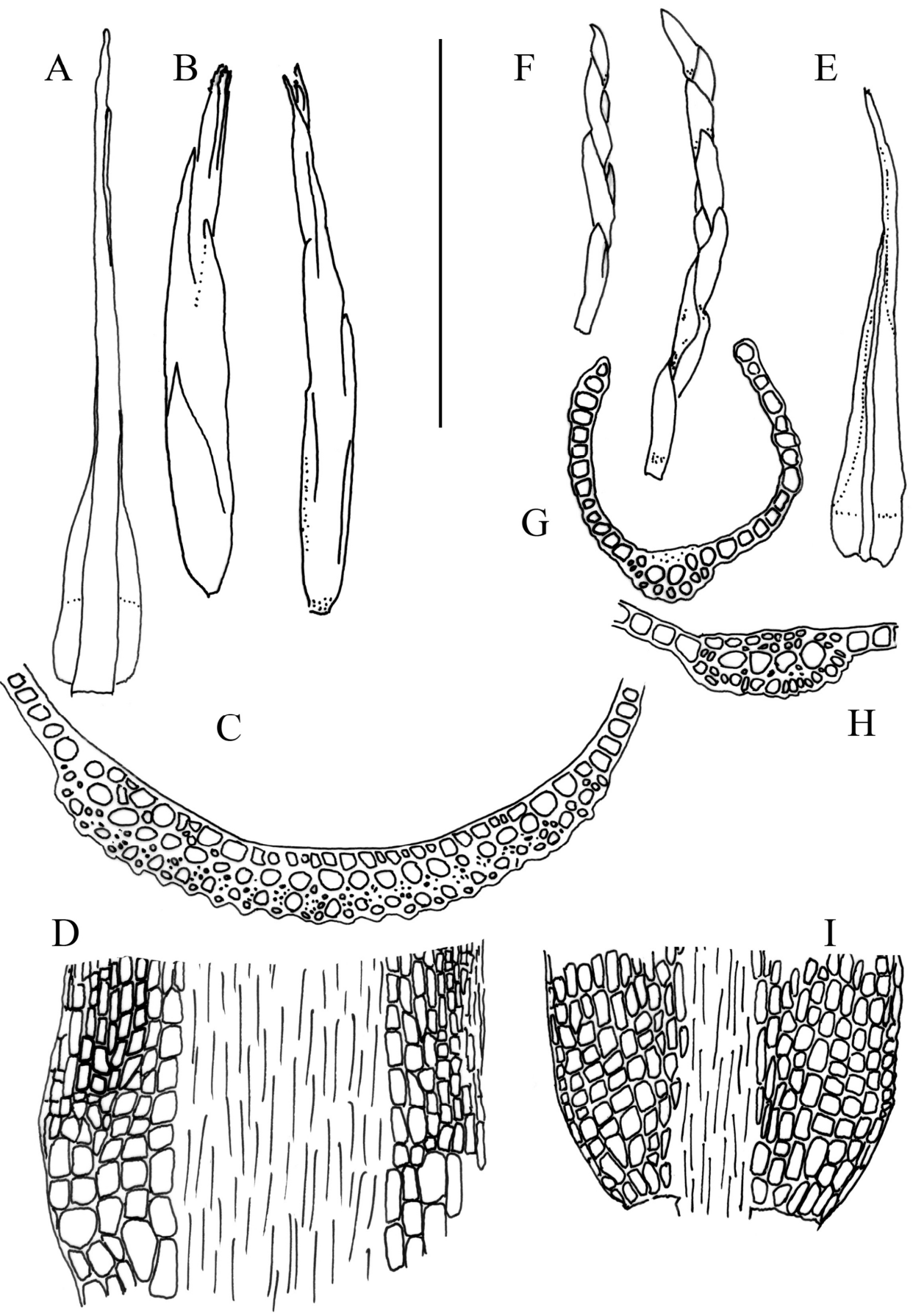


1. ábra. (az előző oldalon) Campylopus flexuosus (B-Erzberger 19163: Pécs, Hideg-völgy 09.10.2014 leg. Csiky \& Erzberger): A levél (2 mm), B száraz flagellumok (2 mm), C az ér keresztmetszeti képe a levél alsó felében $(200 \mu \mathrm{m})$, D a levél alapi része a saroksejtekkel $(400 \mu \mathrm{m})$. A pontozott vonal a levél üvegszerűen áttetsző, alsó, illetve a felsőbb, klorofill tartalmú, zöld része közti átmenetet jelzi (A). Dicranum flagellare (B-Erzberger 6688: Budapest, Nagy Hárs-hegy 07.02.2001 leg. Erzberger): E levél ( $2 \mathrm{~mm}$ ), F száraz flagellumok ( $2 \mathrm{~mm}), \mathbf{G}$ az ér keresztmetszeti képe a levél alsó felében $(200 \mu \mathrm{m}), \mathbf{H}$ a levél felső felének keresztmetszete $(200 \mu \mathrm{m})$, I a levél alapi része a saroksejtekkel $(400 \mu \mathrm{m})($ Peter Erzberger eredeti rajzai).

Fig. 1. (previous page) Campylopus flexuosus (B-Erzberger 19163: Pécs, Hideg-völgy 09.10.2014 leg. Csiky \& Erzberger): A leaf ( $2 \mathrm{~mm})$, B flagella dry ( $2 \mathrm{~mm}), \mathbf{C}$ transverse section of costa in lower part of leaf $(200 \mu \mathrm{m})$, D leaf base with alar cells $(400 \mu \mathrm{m})$. The stippled line indicates the transition from the hyaline basal to the chlorophyllose upper part of leaf (A).

Dicranum flagellare (B-Erzberger 6688: Budapest, Nagy Hárs-hegy 07.02.2001 leg. Erzberger): E leaves $(2 \mathrm{~mm}), \mathbf{F}$ flagella dry $(2 \mathrm{~mm}), \mathbf{G}$ transverse section of costa in lower part of leaf $(200 \mu \mathrm{m}), \mathbf{H}$ transverse section of upper part of leaf $(200 \mu \mathrm{m})$, I leaf base with alar cells $(400 \mu \mathrm{m})$ (Original drawings of Peter Erzberger).

Érdemes megemlíteni, hogy a legközelebbi magyarországi rokon faj, az özönnövény Campylopus introflexus a Mecsekben is terjedőben van, állományai az országban itt a legnagyobbak (SzúCS et al. 2014), s korábban a területről ezt sem jelezték (vö. CSIKY et al. 2014). A két faj makroszkopikus megjelenésében jelentősen különbözik, mivel a $C$. introflexus levélkéje fejlett hyalin-csúccsal rendelkezik, amely száraz állapotban szürkészöldre színezi a telepet (a $C$. flexuosus levélkéjének nincs hyalin-csúcsa). Élőhelyi preferenciájuk is eltérő: míg a $C$. flexuosus a hűvös, üde, felnyíló, mészkerülő bükkösben és tölgyesekben él (vö. ERZBERGGER \& NÉMETH 2014), addig a C. introflexus a melegebb, szárazabb, felnyíló, mészkerülő tölgyesekben hódít. A két faj azonban alkalmanként együtt is előfordul (például Babásszerkövek, Sasfészek és Zsongorkő környéke, Fonyó-hát, Páprágy-völgy), olyan területeken, ahol a mészkerülő tölgyesek és a bükkösök, a szárazabb és az üdébb állományok érintkeznek egymással.

A Mecsekben mindkét Campylopus faj további terjedése várható, elsősorban a jelentős mohaszinttel rendelkező mészkerülő erdőkben. Ez a tendencia nem meglepő. A közeli Csehország területén az őshonosnak tartott, de korábban rendkívül ritka C. flexuosus napjainkra elterjedté vált, míg az adventív $C$. introflexus a feltehetőleg egyetlen emberi tevékenységek hatására terjedô inváziós moha (KUČERA et al. 2012).

Magyarországon a $C$. flexuosus őshonosságának kérdése nehezen vizsgálható. Első példányai 1953-ból származnak (lásd feljebb), s lelőhelyén akkoriban is feltehetőleg ritka lehetett. A mecseki termőhelyein a 20. században még nem gyüjtötték. Felvetődik a kérdés, hogy ilyen estekben az edényes növényeknél alkalmazott (MIHÁLY \& BoTTA-DuKÁT 2004) honossági besorolások, illetve ezek definíciói mennyiben alkalmazhatók a közelmúltig kevéssé kutatott, apró termetű, könnyen terjedő mohafajokra. Amennyiben a $C$. flexuosus újjövevény (neofiton) jellege bizonyítható lenne, terjeszkedése alapján potenciálisan invazív (özön) fajként kezelhetnénk. Amennyiben elfogadjuk őshonosnak, csupán expanzív (terjeszkedő) mohaként vehetjük figyelembe.

Említésre méltó továbbá, hogy a Jakabhegy platójának déli letöréseinél (6/e, k) kísérő fajként jelenik meg a Campylopus fragilis (Brid.) Bruch \& Schimp. is, amely Magyarország mohaflórájának új eleme (vö. DEME et al. 2015). A magyarországi Campylopus fajok morfológiai különbségeinek, elterjedésének, termőhelyi preferenciájának sajátságairól egy másik, határozókulccsal ellátott cikkben számolunk be. 


\section{Köszönetnyilvánítás}

Ezúton köszönjük Márkus András, Szabó László Gyula és Papp Beáta irodalmazásban nyújtott segítségét. Köszönetünket fejezzük ki továbbá az MTM (BP) Mohagyűjtemény igazgatójának és kurátorának a herbáriumi példányok rendelkezésre bocsájtásáért, valamint lektorunknak gondos munkájáért és előremutató javaslataiért.

\section{Irodalomjegyzék}

BoRHIDI A. (2003): Magyarország növénytársulásai. - Akadémiai Kiadó, Budapest, 610 pp.

Boros Á. (1968): Bryogeographie und Bryoflora Ungarns. - Akadémiai Kiadó, Budapest.

CSIKY J., ATKÁRI B., DEME J. \& CSIKYNÉ R.E. (2014): Mohaflorisztikai érdekességek a Nyugat-Mecsekből. Kitaibelia 19: 29-38.

Deme J., Csiky J. \& ERzBerger, P. (2015): Campylopus fragilis (Brid.) Bruch \& Schimp. [Hungary]. - In: ElLiS, L.T. (ed.), New National and Regional Bryophyte Records. - Journal of Bryology 37 (in press).

ERZBERGER, P. \& NÉMETH Cs. (2014): Új faj Magyarország mohaflórájában: Campylopus flexuosus (Hedw.) Brid. - Kitaibelia 19: 22-28.

Fodor A. \& SzURDoki E. (2014): Dél-Dunántúl tőzegmohás élőhelyei. - Természetvédelmi Közlemények 20: 24-49.

Frahm, J.-P. \& FreY, W. (1992): Moosflora. 3. überarbeitete Auflage. - Verlag Eugen Ulmer, Stuttgart, 528 pp.

Hill, M.O., Bell, N., Bruggeman-Nannenga, M.A., Brugués, M., Cano, M.J., Enroth, J., Flatberg, K.I., Frahm, J.P., Gallego, M.T., Garilleti, R., Guerra, J., Hedenäs, L., Holyoak, D.T., Hyvönen, J., Ignatov, M.S., Lara, F., MAZimpaKA, V., MunOZ, J. \& SöDERSTRÖM, L. (2006): An annotated checklist of the mosses of Europe and Macaronesia. - Journal of Bryology 28: 198-267.

Kevey B. \& Borhidi A. (2005): The acidophilous forests of the Mecsek and their realtionship with the Balkan-Pannonian acidophilous forests. - Acta Botanica Hungarica 47: 273-368,

KIRÁLY G. (szerk.) (2009): Új magyar füvészkönyv. Magyarország hajtásos növényei. Határozókulcsok. ANPI, Jósvafó, 616 pp.

KonRÁd Gy., SEBe K., HalÁSz A. \& HAlmai Á. (2010): A Dél-Dunántúl földtani fejlődéstörténete - recens analógiák. - Földrajzi Közlemények, 134: 251-265.

KuČERA, J., VÁŇA, J. \& HRADíLEK, Z. (2012): Bryophyte flora of the Czech Republic: updated checklist and Red List and brief analysis. - Preslia 84: 813-850.

MıнÁLY B. \& BотTA-DukÁT Z. (szerk.) (2004): Biológiai inváziók Magyarországon. Özönnövények. A KvVM Természetvédelmi Hivatalának Tanulmánykötetei 9. - TermészetBúvár Alapítvány Kiadó, Budapest, 408 pp.

ORBÁN S. \& VAJDA L. (1983): Magyarország mohaflórájának kézikönyve. - Akadémiai Kiadó, Budapest, 518 pp.

PAPP B. (2010): Néhány aktuális adat Pécs környékének érdekes, ritka moháiról - egy fontos mohavédelmi terület kijelölése. - Dunántúli Dolgozatok (A) Természettudományi sorozat 12: 42-50.

PApp B., ERZberger, P., Ódor P., Hock Zs., SzövÉNyi P., Szurdoki E. \& Tóth Z. (2010): Updated checklist and red list of Hungarian bryophytes. - Studia Botanica Hungarica 41: 31-59.

Sмiтн, A. J. E. (2004): The moss flora of Britain and Ireland. 2nd Edition. - Cambridge University Press, Cambridge, New York, 1026 pp.

SzÚcs P., CsiKY J. \& PAPP B. (2014): A neofiton Campylopus introflexus (Hedw.) Brid. elterjedése Magyarországon. - Kitaibelia 19: 212-219.

Beérkezett / received: 2015. 01. 23. • Elfogadva / accepted: 2015. 02. 16. 